www.czasopisma.marszalek.com.pl/pl/10-15804/npw

\author{
ELŻBIETA KOLASIŃSKa \\ Uniwersytet Gdański \\ ORCID: https://orcid.org/0000-0001-6592-5598
}

\title{
Konsumpcja dóbr luksusowych w Chinach
}

\section{The Consumption of Luxury Goods in China}

\section{Abstract}

The consumption of luxury goods is a complex phenomenon influenced by many factors and variables. It is the result of national and global conditions. The article investigates the consumption of luxury goods in China, the demand for which is increasing each year. This is a relatively new topic and subject of research in various social sciences. The author analyses this phenomenon from the point of view of Chinese society, which has evolved and started to develop dynamically in recent years. The study discusses the concept of consumption with particular emphasis on luxury goods, and also presents some critical remarks regarding the consumption of these products.

The article is a theoretical-empirical study and it is based on classical and contemporary literature on consumption, as well as selected foreign research on the issue of luxury goods consumption in China. The article has a scientific value and can also be used to analyse the demand and supply of luxury goods in Chinese society.

Keywords: consumption, luxury goods, Chinese society, consumers

\section{Потребление предметов роскоши в Китае}

\section{Аннотация}

Потребление предметов роскоши - сложное явление, на которое влияет множество факторов и переменных. Это результат национальных, как и глобальных условий. 
Цель статьи - представить потребление предметов роскоши в Китае, где спрос на них растет ид года в год. Обсуждаемая тема является новой и представляет предмет исследований в различных социальных науках. Автор сосредоточивает внимание на анализе этого явления с точки зрения китайского общества, которое в последние годы эволюционировало и начало динамично развиваться. В исследовании обсуждается понятие потребления, с особым ударением на предметы роскоши, а также представлены некоторые критические замечания относительно потребления престижных товаров.

Статья представляет собой теоретически-эмпирическое исследование, в котором была использована классическая и современная литература на тему потребления, а также избранные зарубежные исследования по проблеме потребления предметов роскоши в Китае. Статья имеет научную и прикладную ценность, а также может быть использована практиками для анализа спроса и предложения предметов роскоши в китайском обществе.

Ключевые слова: потребление, предметы роскоши, китайское общество, потребители

\section{Wprowadzenie}

Tonsumpcja to złożone zagadnienie, które posiada bogatą tradycję. Obok —terminu „konsumpcja” używa się również pojęcia „spożycie” (Bywalec, Rudnicki, 2002). Na konsumpcję wpływają różne systemy, począwszy od gospodarczego, poprzez społeczno-kulturowy, a na politycznym kończąc. Konsumpcja jest zakorzeniona w określonym społeczeństwie, które wyznacza wzory, normy, style konsumowania i postawy wobec konsumpcji. Na wybór określonego wzorca konsumpcji danej jednostki mają wpływ jej poziom ekonomiczny, przynależność społeczna, wyposażenie gospodarstwa domowego, poziom kultury i tradycje kulturowe (Bylok, 2005). Style konsumowania dóbr i usług są swoistymi działaniami jednostek, grup, zbiorowości i są efektem ich wyborów. Wśród naukowców można wyróżnić różne podejścia do konsumpcji. Jedni postrzegają ją afirmacyjnie i przypisują jej pozytywne konotacje. Drudzy mają do niej stosunek krytyczny i opisują ją jako zjawisko negatywne. Inni jeszcze przejawiają postawy ambiwalentne. Problematyka konsumpcji jest zagadnieniem interdyscyplinarnym, podejmowanym przez przedstawicieli różnych nauk społecznych i nie tylko.

Ekonomiści analizują konsumpcję w kontekście zaspakajania potrzeb (Lange, 1978; Kramer, 1997), wykorzystania (zużywania) dóbr materialnych 
i usług (Pohorille, 1980), popytu na dane dobro lub usługę (Nasiłowski, 2000), konsumenta na rynku (Smyczek, Sowa, 2005), racjonalnych wyborów (Chojnacka, 2014), a także dóbr rzadkich i rynku (Światowy, 2006).

Psychologowie opisują konsumpcję w odniesieniu do emocji (Derbaix, Pham, 1991), zachowań (Falkowski, Tyszka, 2009; Tyszka, 2010) czy wartości kultury (Zawadzka, Niesiobędzka, Godlewska-Werner, 2014).

Socjologowie analizują konsumpcję w kontekście potrzeb (Szczepański, 1981), kultury (Bylok, 2005; Krajewski, 2004; Sassatelli, 2007), nowoczesności (Slater, 1997), zjawiska konsumeryzmu (Bauman, 2009), tożsamości (Giddens, 2010), sposobu na życie (Miles, Tucker, 1998), konsumpcji na pokaz i statusu (Veblen, 1971; Cebula), religii, (Golka, 2004; Kossakowski, 2011; Weber, 2002), społeczeństwa konsumpcyjnego i modeli konsumpcji (Ritzer, 2001), czasu wolnego (Stebbins, 2009), konsumpcjonizmu (Bylok, 2013).

Celem artykułu jest przedstawienie konsumpcji dóbr luksusowych w społeczeństwie chińskim. W opracowaniu przede wszystkim poszukuję odpowiedzi na następujące pytania: jaka jest rola konsumpcji dóbr luksusowych w społeczeństwie chińskim? jakie są główne uwagi krytyczne do konsumpcji dóbr luksusowych w Chinach?

\section{Istota i pojęcie konsumpcji}

Termin „konsumpcja” po raz pierwszy zastosował J.B. Schupp w 1963 roku dla określenia spożycia dóbr. Rodowód tego pojęcia sięga starożytności i pierwotnie oznaczało ono po pierwsze spożywanie i użytkowanie dóbr, a po drugie marnotrawienie i nabywanie dóbr (Bylok, 2005, s. 12). „Konsumpcja bywa traktowana jako konstytutywny atrybut współczesnej cywilizacji określanej jako kultura konsumpcyjna, społeczeństwo konsumpcyjne, kapitalizm konsumencki" (Lewicka-Strzałecka, 2003, s. 132).

„Wyróżniamy trzy różne zjawiska i procesy nazywane konsumpcją:

1. Bezpośredni akt spożycia, czyli bezpośrednie zaspokojenie pewnej potrzeby poprzez zużycie określonego środka,

2. Proces złożony z działań i zachowań człowieka zmierzający do pośredniego i bezpośredniego zaspokajania potrzeb,

3. Faza procesu reprodukcji społecznej, tzn. ta część gospodarki narodowej w skali makro, którą można nazwać także „sferą spożycia”, na którą 
składają się „warunki życia społecznego", warunki pracy, poziom życia ludności, fundusz spożycia - słowem to wszystko, co w gospodarce narodowej ma pośredni lub bezpośredni związek z zaspokajaniem potrzeb ludności” (Szczepański, 1981, s. 132).

Z konsumpcją możemy powiązać zjawisko konsumpcjonizmu, które oznacza „styl życia, który nastawiony jest w głównej mierze na konsumowanie i posiadanie, a wręcz przesadne zainteresowanie konsumpcją" (Aldridge, 2006, s. 14-15). „Konsumpcjonizm staje się specyficznym sposobem życia, który związany jest z nadmiernym nabywaniem i spożywaniem dóbr" (Bylok, 2013, s. 57). „Członkowie społeczeństwa konsumentów są sami towarami konsumpcyjnymi i ta właśnie właściwość czyni ich bona fide członkami społeczeństwa" (Bauman, 2009, s. 66). Zachowania konsumentów to splot działań ukierunkowanych na nabywanie produktów lub usług na rynku. Są one efektem podjętych decyzji przez klienta, który dąży do zaspokojenia swoich potrzeb konsumenckich, zarówno racjonalnych, jak i irracjonalnych w określonym czasie.

Specyficznym typem konsumpcji jest „konsumpcja ostentacyjna” (Veblen, 1971). Stanowi ona przykład zachowania na pokaz i jej celem jest kreowanie takiego obrazu własnej osoby, aby podkreślać status społeczny (Veblen, 1971). Konsumpcja ostentacyjna klasy próżniaczej koncentrowała się nie na wartości użytkowej dóbr, ale na konsumowaniu dóbr luksusowych na pokaz (Veblen, 1971). „Konsumpcja ostentacyjna” jest celowym działaniem ukierunkowanym na posiadanie symbolicznych produktów i usług, aby komunikować innym wyróżniający obraz siebie (Chaudhuri, Mazumdar, Ghoshal, 2011). „Konsumpcja ostentacyjna” polega na wykorzystaniu efektu społecznego przy zakupie luksusowych dóbr. Po pierwsze konsument dąży do zaspokojenia indywidualnej potrzeby posiadania markowych dóbr, a po drugie ich wybór jest celowym zachowaniem ukierunkowanym na wywarcie wrażenia na innych poprzez sam fakt ich posiadania. Im bardziej luksusowe dobro, tym bardziej jest ono eksponowane publicznie. „Niektóre gospodarstwa domowe nabywają tym większe ilości danego dobra, im jest ono droższe. Korzyść konsumpcyjna polega wówczas na demonstrowaniu swoich możliwości konsumpcyjnych” (Klimczak, 1995, s. 78). „Konsumpcja ostentacyjna nazywana bywa również konsumpcją demonstracyjną, która definiowana jest jako wzór działania polegający na tym, że jednostka dąży 
do zamanifestowania swojej siły pieniężnej przez nabywanie i pokazywanie dóbr i usług podwyższających jej prestiż (status) w oczach innych" (Cebula, 2013, s. 10). Nadawanie dobrom luksusowym wartości prestiżowych stanowi podstawę decyzji konsumenckich. Wybory konsumentów dotyczące pokazowego konsumowania dóbr luksusowych mogą być podyktowane zaspokojeniem potrzeby wyróżnienia się na tle innych. „Efekt konsumpcji na pokaz" jest wykorzystywany nie tylko w aspekcie krajowym, ale również mamy do czynienia z międzynarodowym efektem pokazowym (Nurkse, 1953).

\section{Konsumpcja dóbr luksusowych w Chinach}

Dobra luksusowe są określane jako prestiżowe. Oprócz zaspokajania potrzeb wyższych mogą one służyć do eksponowania statusu materialnego. Konsumenci dóbr luksusowych poprzez manifestowanie stanu posiadania dążą do kreowania swojego wizerunku osoby zamożnej. Innym motywem może być zapewnienie sobie dobrostanu psychicznego i poczucia materialnego bezpieczeństwa. Dobra luksusowe służą do zaspokajania ekstrawaganckich potrzeb konsumenta. Nabywcy dóbr luksusowych kierują się przyjemnością w zaspokajaniu zachcianek, wywołaną upodobaniem do przepychu, zamożności, konsumpcji na pokaz, komfortu czy zbytku (Sikora, 2002, s. 138).

Konsumpcja dóbr luksusowych w Chinach jest uwarunkowana różnymi czynnikami. Po pierwsze w społeczeństwie chińskim zauważalny jest wyraźny wzrost liczby ludzi bogatych z klasy średniej i wzrost dochodu miejskich gospodarstw domowych, po drugie $\mathrm{z}$ roku na rok wzrasta produkt krajowy brutto i dynamicznie rozwija się prywatna przedsiębiorczość, a także rysuje się dla kraju perspektywa bycia największą gospodarką świata (Por. Kupś et al., 2021; Marszałek-Kawa, Dmochowski, 2018). Kolejnymi czynnikami są kolektywizm, konfucjańska etyka pracy i tradycyjne wartości społeczeństwa chińskiego, które uważa drogie dobra konsumpcyjne za wyznaczniki sukcesu. Innym czynnikiem jest adaptacja trendów konsumpcyjnych z innych państw, których nośnikiem jest globalizacja (Meyer, 2015, s. 240-248).

Warto również podkreślić, że rozwój Chin dokonuje się w oparciu o przyjętą przez władzę strategię, opartą na klasie średniej, eksporcie i rynku wewnętrznym (Por. Góralczyk, 2018). Jej fundamenty nakreślił Xi Jinping 
w swoim referacie na zjeździe Komunistycznej Partii Chin. Wymienił on dwa cele stojące przed państwem i partią, które nazwał „dwa cele stulecia” (liangge yi bai nian) w odniesieniu do daty powstania KPCh. W pierwszym chodzi o zbudowanie „społeczeństwa umiarkowanego dobrobytu” (xiaokang shehui), utożsamianego z klasą średnią, a w drugim, realizowanym pod hasłem "wielkiego renesansu narodu chińskiego" (Zhonghua minzu weida fuxing), chodzi o zbudowanie harmonijnego społeczeństwa. Ma on być osiągnięty do 1 października 2049 roku (Góralczyk, 2017, s. 290-291). „Co znaczące, Xi Jinping połączył hasło mówiące o »renesansie« $\mathrm{z}$ »chińskim marzeniem «. Tym samym obecnie obowiązująca mantra brzmi: »wielki renesans narodu chińskiego to chińskie marzenie «" (Góralczyk, 2017, s. 291). Przywódca powiedział: „ścieżka, teoria, system i kultura socjalizmu o chińskich cechach nadal się rozwijają, oświetlając nowy szlak i pokazując innym narodom i krajom rozwijającym się, jak się zmodernizować” (Kołodko, 2018, s. 658). „Xi Jinping dąży do utworzenia państwa silnego pod względem politycznym, gospodarczym oraz militarnym, o silnej i ugruntowanej pozycji międzynarodowej" (Wardęga, 2015, s. 178; por. Marszałek-Kawa, 2010; 2014). Chiny dążą do tego, aby zostać światowym hegemonem, którego rozwój opiera się na eksporcie, konsumpcji i rynku wewnętrznym (Brunet, Guichard, 2011). Rozwój

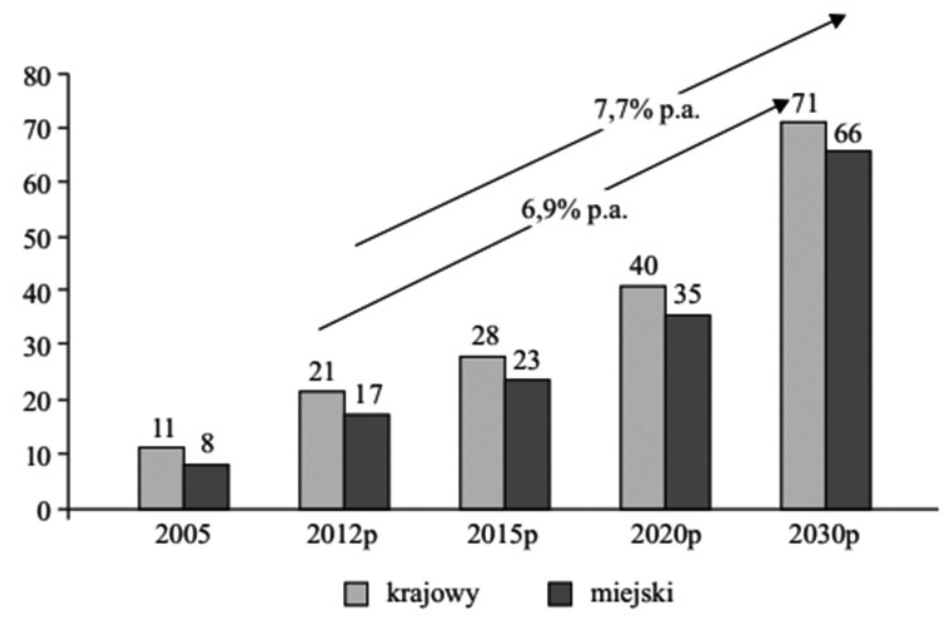

Rysunek 1. Całkowity dochód gospodarstw domowych w juanach w (\%) Wzrost realnego PKB, Chiny: 6,5\%, 2012-2030.

Źródło: Jałowiecki, 2014, s. 218, cyt. za Global Insights; McKinsey Insights China. 
Państwa Środka jest nierównomierny, a społeczeństwo jest zhierarchizowane, o dużym poziomie nierówności między miastami a wsiami. Jednak wzrost dochodu krajowego, jak i wzrost dochodu miejskich gospodarstw domowych stanowi siłę napędową konsumpcji wewnętrznej. Całkowity dochód gospodarstw domowych miejskich, jak i krajowych w odniesieniu do 2030 roku wzrośnie (rys. 1). Taki stan rzeczy zwiększy jeszcze dysproporcje dochodowe i nierówności między mieszkańcami miast i wsi.

Na postawie danych dotyczących dochodu chińskich gospodarstw domowych możemy stwierdzić, że w społeczeństwie chińskim wzrósł dochód klasy najwyższej w 2017 roku o 9,1 proc., czyli o 0,8 pkt. procentowych w stosunku do roku poprzedniego. Klasa średnia wyższa odnotowała wzrost na poziomie 7,7 proc., natomiast klasa średnia wzrost o 7,2 proc., a klasa średnia niższa wzrost o 7,1 procent (Forsal, 2018).,W 2019 roku roczny dochód mieszkańców wschodnich Chin wyniósł około 39439 juanów. Natomiast w 2019 roku około 3,23 miliona mieszkańców wsi w zachodnich Chinach żyło za mniej niż 2300 juanów rocznie" (Statista, 2020).W porównaniu z bardziej uprzemysłowionymi wschodnimi regionami przybrzeżnymi, regiony zachodniego wybrzeża są mniej rozwinięte pod względem urbanizacyjnym, technologicznym, ekonomicznym i społecznym. Dysproporcje te są zauważalne w relacjach miasto - wieś oraz regionalnie: wschodnia - zachodnia cześć Państwa Środka (Statista, 2020). Na podstawie danych empirycznych możemy stwierdzić, że nierówności dochodowe i społeczne korelują z konsumpcją, a także poziomem życia. Konsumpcję wewnętrzną, a szczególnie konsumpcję dóbr luksusowych, napędzają metropolie i duże miasta wokół wschodniego wybrzeża, a przede wszystkim zamożna klasa średnia, która jest beneficjentem reform. Natomiast prowincje zachodnie w minimalnym stopniu korzystają z krajowego dobrobytu i w praktyce nie uczestniczą w konsumowaniu dóbr luksusowych (McKinsey \& Company, 2019). Wzrost konsumpcji dóbr luksusowych stanowi efekt rozwoju Państwa Środka, ale jednocześnie jest, jak stwierdzili Schell i Delury, „wyrazem niepisanej umowy Chińczyków z partią, która przyjęła formułę: »jeśli wolno będzie się nam bogacić i dążyć do lepszego standardu życia, i jeśli kraj nasz będzie coraz bardziej zmierzał w kierunku dobrobytu i mocarstwowej pozycji w świecie, to nie będziemy próbowali podważać rządów autorytarnych""(Walkowski, 2017, s. 348).

Biorąc pod uwagę poziom nierówności w Chinach możemy stwierdzić, że pod koniec lat 70 . były one niższe niż średnia europejska - zbliżały się do 
poziomu krajów nordyckich, ale od 2015 roku poziom nierówności zaczął wzrastać i obecnie jest porównywalny do poziomu z USA (LSE Business Review, 2019). Z kolei na podstawie współczynnika Giniego, którym mierzone są nierówności społeczne, wyniósł on w 2017 roku 0,467 i jest to wzrost o 0,002 w odniesieniu do 2016 roku, natomiast w 2019 roku osiągnął poziom 46,5 (Statistica, 2020).

Według raportu Bain \& Company zmniejszenie ceł i kontrola szarej strefy sprawiły, że większa liczba chińskich konsumentów kupuje produkty luksusowe w Chinach, zamiast podróżować do różnych miast europejskich. W 2018 roku 27 proc. chińskich konsumentów dokonało zakupów dóbr luksusowych, co stanowi o 23 proc. więcej niż w 2015 roku. Wskaźnik ten wzrośnie do roku 2025 o 50 proc. Chińscy konsumenci nie tylko kupują dobra luksusowe w Chinach, ale również za granicą, a ich wydatki na niniejsze dobra stanowią obecnie 33 proc. światowego rynku. Jednak rynek osobistych dóbr luksusowych spadł o 25 proc. w pierwszym kwartale roku, gdy COVID-19 rozprzestrzenił się w Azji, a następnie na całym świecie. Odzyskanie rynku zajmie trochę czasu, a nastąpi dopiero w 2022 lub 2023 roku (2019, s. 3).

Natomiast, jak wynika $\mathrm{z}$ kolejnego raportu przeprowadzonego przez McKinsey \& Company, w 2019 roku Chiny odpowiadały za ponad połowę światowego wzrostu wydatków na luksus w latach 2012-2018 i możemy się spodziewać, że do 2025 roku ów wskaźnik wzrośnie do 65 proc. Wzrost ten będzie napędzany głównie przez gospodarstwa domowe wyższej klasy średniej, której dochody do 2025 roku będą stopniowo wzrastać (2019, s. 4). Klasa średnia w 2015 roku liczyła 300 mln osób, a przewidywano, że w 2020 roku będzie liczyła 45 proc. ludności chińskiej. Klasę tę wyodrębnia się ze społeczeństwa na podstawie wykształcenia, wzorców konsumpcji oraz posiadanych dóbr materialnych. To konsumenci zainteresowani produktami zagranicznymi, uznawanymi za wyższej jakości, znanych marek (Wardęga, 2015, s. 177).

Wzrost liczby członków klasy średniej i jej ewolucja oznaczają pojawienie się nowej dominującej siły na rynku, która składa się z wyrafinowanych i doświadczonych konsumentów. Będą oni mogli wydawać większe części swego dochodu na dowolne produkty i usługi niebędące koniecznością. Jednak tego typu procesy nie będą obejmowały obszarów wiejskich ze względu na zróżnicowanie chińskiego społeczeństwa (Meyer, 2015, s. 244). 
Konsumowanie dóbr luksusowych przez klasę średnią powoduje, że gromadzi ona kapitał materialny, który czyni z niej klasę uprzywilejowaną i dominującą. Akumulacja kapitału pozwala wymieniać go na inne ekskluzywne wartości. Wzrost znaczenie klasy średniej jeszcze bardziej eskaluje hierarchizację społeczeństwa i zamiast niwelować nierówności społeczne pogłębia je.

Rozważając kwestie popytu na dobra konsumpcyjne, a szczególnie luksusowe, trzeba przyjrzeć się zmianom zachodzącym w chińskich miastach. Dzieli się je na grupy uszeregowane zgodnie $\mathrm{z}$ ich rangami wynikającymi z wielkości dochodu, populacji, PKB. Bierze się tu pod uwagę wiele kryteriów, m.in.: rozwój gospodarczy, PKB prowincji, zaawansowane systemy transportowe i infrastrukturę, a także historyczne i kulturowe znaczenie (Oziewicz, 2015, s. 115).

Zainteresowanie dobrami luksusowymi zależy od siły nabywczej konsumentów, jednak nie można zapominać o czynnikach niematerialnych i politycznych, a także światopoglądowych, które mogą stanowić istotne determinanty zachowań konsumenckich. Im bardziej światłe i wyedukowane społeczeństwo, tym bardziej świadomie podejmuje różne decyzje konsumenckie.

Prawdopodobnie hitem w sektorze luksusowym są samochody, torebki, zegarki i elektronika. Luksusowa odzież i biżuteria pozostały stabilne - $60 \%$ respondentów z Hongkongu i 70\% Chińczyków z kontynentu twierdzi, że kupiło luksusową odzież i biżuterię w ciągu ostatnich 12 miesięcy" (Campaign, 2020).

Biorąc pod uwagę konsumentów w społeczeństwie chińskim możemy stwierdzić, że występuje ich strukturalny podział pod względem dochodu, przedmiotu zakupów, miejsca, i kategoryzacji konsumentów (Meyer, 2015, s. 243). Ten podział powoduje, że mamy duże zróżnicowanie konsumentów, a szczególnie widoczna jest przepaść między konsumentami na granicy ubóstwa, a konsumentami dóbr luksusowych. Niniejszy podział jest odzwierciedleniem stratyfikacyjnego charakteru społeczeństwa chińskiego, które jest bardzo zróżnicowane pod względem materialnym, jak wynika $\mathrm{z}$ danych zaprezentowanych $\mathrm{w}$ tabeli 1 . 
Tabela 1. Strukturalny podział chińskich konsumentów

\begin{tabular}{|c|c|c|c|c|c|}
\hline $\begin{array}{c}\text { Kategoria } \\
\text { konsumentów }\end{array}$ & $\begin{array}{c}\% \\
\text { w całości } \\
\text { populacji }\end{array}$ & $\begin{array}{l}\text { Dochód per } \\
\text { capita USD }\end{array}$ & $\begin{array}{c}\text { Ogólne } \\
\text { kryterium } \\
\text { klasyfikacji }\end{array}$ & $\begin{array}{l}\text { Przedmiot } \\
\text { zakupów }\end{array}$ & $\begin{array}{c}\text { Miejsce } \\
\text { zakupów }\end{array}$ \\
\hline $\begin{array}{l}\text { Na granicy } \\
\text { ubóstwa }\end{array}$ & 16,10 & Poniżej 300 & $\begin{array}{l}\text { Nie posiadają } \\
\text { odbiorników } \\
\text { TV }\end{array}$ & $\begin{array}{l}\text { Produkty } \\
\text { niemarkowe }\end{array}$ & $\begin{array}{l}\text { Są samowystar- } \\
\text { czalni, targ }\end{array}$ \\
\hline $\begin{array}{l}\text { Konsument } \\
\text { główny }\end{array}$ & 31,60 & $300-800$ & $\begin{array}{l}\text { Posiadają } \\
\text { odbiorniki } \\
\text { TV }\end{array}$ & $\begin{array}{l}\text { Produkty } \\
\text { niemarko- } \\
\text { we tanie } \\
\text { podstawowe } \\
\text { produkty }\end{array}$ & $\begin{array}{l}\text { Targi, } \\
\text { mokre targi } \\
\text { (wet markety) }\end{array}$ \\
\hline $\begin{array}{l}\text { Konsument } \\
\text { kierujący się } \\
\text { ceną }\end{array}$ & 19,70 & $800-1500$ & $\begin{array}{l}\text { Posiadają } \\
\text { lodówki }\end{array}$ & Marki lokalne & $\begin{array}{l}\text { Tanie sklepy } \\
\text { spożywcze }\end{array}$ \\
\hline $\begin{array}{l}\text { Konsument } \\
\text { kierujący się } \\
\text { jakością }\end{array}$ & 18,70 & $1500-3000$ & $\begin{array}{l}\text { Posiadają } \\
\text { klimatyzatory }\end{array}$ & Średnie marki & $\begin{array}{l}\text { Sieci sklepów } \\
\text { spożywczych }\end{array}$ \\
\hline $\begin{array}{l}\text { Konsumenci } \\
\text { marek }\end{array}$ & 12,30 & $3000-6000$ & $\begin{array}{l}\text { Posiadają } \\
\text { komputery }\end{array}$ & $\begin{array}{l}\text { Marki } \\
\text { narodowe, } \\
\text { średnie marki } \\
\text { globalne }\end{array}$ & $\begin{array}{l}\text { Domy towarowe } \\
\text { lub sklepy } \\
\text { luksusowe }\end{array}$ \\
\hline $\begin{array}{l}\text { Konsumenci } \\
\text { luksusowi }\end{array}$ & 1,60 & Powyżej 6000 & $\begin{array}{l}\text { Posiadają } \\
\text { samochody }\end{array}$ & $\begin{array}{l}\text { Najlepsze } \\
\text { marki } \\
\text { globalne }\end{array}$ & $\begin{array}{l}\text { Luksusowe } \\
\text { domy towarowe } \\
\text { lub zakupy } \\
\text { zagraniczne }\end{array}$ \\
\hline
\end{tabular}

Źródło: Meyer, 2015, s. 243.

Podział konsumentów jest przykładem ich pozycjonowania ze względu na ich wybory konsumenckie. Ich preferencje konsumenckie mogą świadczyć po pierwsze o ich poziomie materialnym, a po drugie o ich preferencjach.

\section{Kilka uwag krytycznych o konsumpcji dóbr luksusowych w Chinach}

Analizując konsumpcję dóbr luksusowych w Chinach możemy stwierdzić, że podobnie jak w innych krajach może ona mieć nie tylko konotacje pozytywne, ale i negatywne. W niniejszym tekście koncentruję się na aspektach negatywnych konsumpcji dóbr luksusowych w Chinach. Do głównych 
negatywnych aspektów należy dyferencjacja społeczeństwa chińskiego, a więc podział na ludzi ubogich i bogatych. Ci pierwsi żyją na granicy ubóstwa, a ci drudzy korzystają z luksusu poprzez między innymi konsumowanie różnych dóbr luksusowych. Chociaż jest to zjawisko obecne w każdym kraju, to w społeczeństwie chińskim te dysproporcje są szczególnie widoczne. Innym mankamentem jest pokazowa konsumpcja dóbr luksusowych, która staje się dominującym celem. Świadectwem na pozorowanie luksusu jest powołany start-up o nazwie Dou Baobao, w którym po zalogowaniu na koncie na platformie WeChat i wpłacie określonej kwoty uzyskuje się możliwość wynajęcia luksusowego dobra. W taki sposób działa sharing economy dóbr luksusowych (Business Insider Polska, 2017). Taki stan rzeczy jest przejawem nie tylko konsumowania dóbr luksusowych na pokaz, ale kreowania specyficznego rynku wynajmu tych dóbr.

Kolejnym negatywnym zjawiskiem jest przejęty z Zachodu konsumpcjonizm, szczególnie widoczny w postawach młodych Chińczyków (Bain Company, 2020). Konsumpcja dóbr luksusowych stanowi także przykład fetyszyzmu towarowego, który przybiera postać stosunku między ludźmi a rzeczami (Marks, 1951, s. 77). Konsumenci uzależniają się od posiadania dóbr, które kumulują, by podkreślać swój status materialny i społeczny. „Modus posiadania” według Fromma (1999) jest dla niektórych przedstawicieli społeczeństwa chińskiego motorem działania, stylem życia i na życie. „Ludzie zostają nakłonieni do myślenia, że chcą tych wszystkich towarów i usług, a przynajmniej zostają nakłonieni do myślenia, że ich chcą" (Ritzer, 2001, s. 65). Konsumpcja czyni z nich niewolników dóbr luksusowych. Konsumenci uzależnieni od nabywania dóbr luksusowych stają się marionetkami poruszanymi przez specjalistów od reklamy, którzy wmawiają im, że to dobro jest im niezbędne do życia. „Wartości hedonistyczne dominują w etosie hedonistycznym konsumpcji” (Romaniszyn, 2004)

Dobra luksusowe są oznaką bogactwa i statusu materialnego. Najbardziej prestiżowe dobra sytuują właściciela w konkretnym miejscu hierarchii społecznej czy segmencie rynku. Koncentrację konsumentów na nabywaniu i akumulacji tych dóbr możemy nazwać „ekshibicjonizmem konsumpcyjnym”. Konsumpcja dóbr luksusowych może być podyktowana chęcią zaimponowania innym swoimi dobrami luksusowymi. Może ona być także oznaką materialnego nastawienia do życia, ponieważ odpowiedź z sondażu: 
„mierzę mój sukces przez rzeczy, które posiadam wybrało 71 proc. Chińczyków” (Ipsos, 2013, s. 2). Skupianie się na posiadaniu dóbr luksusowych może świadczyć także o potrzebie manifestowania swojego statusu materialnego na tle innych, którą można aprobować lub dezaprobować.

\section{Podsumowanie}

Konsumpcja dóbr luksusowych w Chinach z każdym rokiem wzrasta i nabiera dynamicznego tempa, dlatego nie można jej marginalizować ani nie doceniać zarówno w Państwie Środka, jak również na poziomie globalnym. Preferencje zakupowe konsumentów dóbr luksusowych są ważnym segmentem rynku i gospodarki. Kształtujące się trendy konsumenckie i popyt na produkty luksusowe są również kluczowymi danymi dla różnych przedsiębiorstw, które je produkują, zbywają i wymieniają.

Konsumpcja dóbr luksusowych w Chinach stanowi przykład rozwoju kraju i wzrostu liczby ludzi bogatych w społeczeństwie chińskim. Pomimo że społeczeństwo chińskie dynamicznie się rozwija, możemy wyróżnić beneficjentów zmian, którymi są konsumenci dóbr luksusowych i obywateli, którzy nie mogą sobie na nie pozwolić z powodu deficytów materialnych.

\section{DR ELŻBIETA KOLASIŃSKA}

\section{Instytut Socjologii \\ Wydział Nauk Społecznych \\ Uniwersytet Gdański \\ ul. Jana Bażyńskiego 4, 80-309 Gdańsk \\ kol8@o2.pl}

\section{Bibliografia}

Aldridge, A. (2006), Konsumpcja, Warszawa: Wydawnictwo Sic!

Bauman, Z. (2009), Konsumowanie życia. Kraków: Wydawnictwo Uniwersytetu Jagiellońskiego.

Brunet, A., Guichard, J. (2011). Chiny światowym hegemonen? Imperializm ekonomiczny Państwa Środka. Warszawa: Studio Emka.

Bylok, F. (2005). Konsumpcja $w$ Polsce i jej przemiany $w$ okresie transformacji. Częstochowa: Wydawnictwa Politechniki Częstochowskiej. 
Bylok F. (2013). Konsumpcja, konsument i społeczeństwo konsumpcyjne we współczesnym świecie. Studium socjologiczne. Katowice: Wydawnictwo Naukowe.

Bywalec, C., Rudnicki, L. (2002). Konsumpcja. Warszawa: Polskie Wydawnictwo Ekonomiczne.

Cebula, M. (2013). Konsumpcja statusowa - między praktyczną świadomością, a strategicznym działaniem. Kultura i Społeczeństwo, 4.

Chaudhuri, H., Mazumdar, S., Ghoshal, A. (2011). Conspicuous Consumption Orientation: Conceptualisation, Scale Development and Validation. Journal of Consumer Behaviour, 10 (4).

Chojnacka, K. (2014). Racjonalność decyzji w teorii ekonomii - kilka refleksji dotyczących wyboru. Studia Ekonomiczne, 180.

Derbaix, Ch., Pham, M.T. (1991). Affective reactions to consumption situations: A pilot investigation. Journal of Economic Psychology, 12.

Falkowski, A., Tyszka, T. (2009). Psychologia zachowań konsumenckich. Gdańsk: Gdańskie Wydawnictwo Psychologiczne.

From, E. (2016). Mieć czy być. Poznań: Wydawnictwo REBIS.

Giddens, A. (2010). Nowoczesność i tożsamość. Ja i społeczeństwo w epoce późnej nowoczesności. Warszawa: Wydawnictwo Naukowe PWN.

Golka, M. (2004). W cywilizacji konsumpcyjnej. Poznań: Wydawnictwo Uniwersytetu Adama Mickiewicza.

Góralczyk, B. (2017). Geostrategia Xi Jinpinga - Chiny ruszają w świat. Rocznik Strategiczny, 22.

Góralczyk, B. (2018). Wielki renesans. Chińska transformacje i jej konsekwencje. Warszawa: Wydawnictwo Akademickie Dialog.

Jacyno, M. (2007). Kultura indywidualizmu. Warszawa: Wydawnictwo Naukowe PWN. Jałowiecki, M. (2014). Rozwój gospodarczy Chin jako głównego centrum gospodarczego świata. Zeszyty Naukowe WSB Poznań, 54 (3).

Klimaczak, B. (1995). Mikroekonomia. Wrocław: Wydawnictwo Akademii Ekonomicznej im. Oskara Langego.

Kołodko, G. (2018). Chińska transformacja ustrojowa: socjalizm czy kapitalizm? Teritum datur. Ekonomista, 6.

Kossakowski, R. (2011). Budda w kulturze konsumpcji. Toruń: Wydawnictwo Adam Marszałek.

Kramer, J. (1997). Konsumpcja w gospodarce rynkowej. Warszawa: PWN.

Kupś, H., Szatkowski, M., Dahl, M. (red.). (2021). 70 lat Chińskiej Republiki Ludowej w ujęciu interdyscyplinarnym. Warszawa: Wydawnictwo Akademickie Dialog.

Lange, O. (1978). Ekonomia polityczna. T. 1 i 2. Warszawa: PWN.

Lewicka-Strzałecka, A. (2003). Konsumeryzm kontra konsumeryzm. Annales. Etyka $w \dot{Z} y c i u$ Gospodarczym, 6.

Marks, K. (2012). Kapitał. Warszawa: Studio Emka.

Marszałek-Kawa, J. (red.). (2010). Chiny supermocarstwem XXI wieku? Rozważania na temat polityki i gospodarki Państwa Środka. Toruń: Wydawnictwo Adam Marszałek.

Marszałek-Kawa, J. (red.). (2014). Globalna polityka Chin. Czynniki i perspektywy. Toruń: Wydawnictwo Adam Marszałek. 
Marszałek-Kawa, J., Dmochowski, T. (red.). (2018). Rozważania o kierunkach współczesnej polityki Chin. Toruń: Wydawnictwo Adam Marszałek.

Meyer, M. (2015). Chiński konsument wobec luksusowych towarów i usług w perspektywie kulturowej. Handel Wewnętrzny, 5.

Miles, S.K., Tucker, H. (1998). Consumerism - as a Way of Life. London: Sage Publications.

Nasiłowski, M. (2000). System rynkowy. Podstawy mikro- i makroekonomii. Warszawa: Wydawnictwo Key Text.

Nurkse, R. (1953). Problems of Capital Formation in Underdeveloped Countries. Oxford, New York: University Press.

Oziewicz, E. (2015). Uwagi na temat chińskiego rynku zbytu towarów konsumpcyjnych ze szczególnym uwzględnieniem dóbr luksusowych. ANALES, XLIX (2).

Pohorille, M. (1980). Potrzeby - podziat - konsumpcja. Warszawa: PWE.

Ritzer, G. (2001). Magiczny świat konsumpcji. Warszawa: Wydawnictwo Muza.

Romaniszyn, K. (2004). Konsumuję więc jestem. Kim właśnie? W: M. Flis (red.). Etyczny wymiar tożsamości kulturowej. Kraków: Nomos.

Sassatelli, R. (2007). Consumer culture: History, theory and politics. London: SAGE.

Sikora, T. (2002). Pojęcie luksusu - definicje i cechy charakterystyczne. International Journal of Management and Economics, 12.

Slater, D. (1997). Consumer culture and modernity. Cambridge: Polity Press.

Smyczek, S., Sowa, I. (2005). Konsument na rynku. Zachowania, modele, aplikacje. Warszawa: Wydawnictwo Difin.

Stebbins, R. (2009). Leisure and Consumption: Common Ground, Separate Worlds. Houndmills, Basingstoke: Palgrave Macmillan.

Szczepański, J. (1981). Konsumpcja a rozwój człowieka. Warszawa: Polskie Wydawnictwo Ekonomiczne.

Światowy, G. (2006). Zachowania konsumentów. Determinanty oraz metody poznania $i$ ksztaltowania. Warszawa: Polskie Wydawnictwo Ekonomiczne

Tyszka, T. (2010). Decyzje. Perspektywa psychologiczna i ekonomiczna. Warszawa: Wydawnictwo Scholar.

Veblen, T. (1971). Teoria klasy próżniaczej. Warszawa: PWN.

Walkowski, M.(2017). Chiński model rozwoju społeczno-gospodarczego i jego potencjalna adaptacja w Europie. Przegląd Strategiczny, 10.

Wardęga, J. (2015). Współczesne społeczeństwo chińskie. Konsekwencje przemian modernizacyjnych. Toruń: Wydawnictwo Adam Marszałek.

Weber, M. (2002). Gospodarka i społeczeństwo. Zarys socjologii rozumiejacej. Warszawa: Wydawnictwo Naukowe PWN.

Williams, R. (1976). Keywords: a vocabulary of culture and society. Glasgow: Fontana.

Zawadzka, A.M., Niesiobędzka, M., Godlewska-Werner, D. (red.). (2014). Kultura konsumpcji - wartości, cele, dobrostan. Psychologiczne aspekty zjawiska. Warszawa: Liberi Libri.

\section{Netografia}

Bain Company 2020. Pobrane z: https://www.cnbc.com/2020/05/08/coroanvirus-bain-report-on-global-luxury-sales-for-2020-and-beyond.html. 
McKinseyぬComany 2019. China Lexury Report. Pobrane z: mckinsey.com/ /media/mckinsey/featured\%20insights/china/how\%20young\%20chinese $\% 20$ consumers $\% 20$ are\%20reshaping\%20global\%20luxury/mckinsey-china.

Campaign 2020. What does China's luxury market look like in 2020? Pobrane z: https://www.campaignasia.com/article/what-does-chinas-luxury-market-look-like -in- 2020/458432.

Ipsos 2013. Global Attitudes on Materialism, Finances and Family. Pobrane z: https://www. ipsos.com/sites/default/files/news_and_polls/2013-12/6359.pdf.

Business Insider Polska 2017. Sharing economy po chinsku. Kogo nie stać, ten „wynajmuje" dobra luksusowe. Pobrane z: https://businessinsider.com.pl/wiadomosci/ dou-baobao-wypozyczalnia-dobr-luksusowych-w-chinach/5nex6te.

Statista 2020. Disposable income per capita in China in 2019, by region (in yuan). Pobrane z: https://www.statista.com/statistics/278854/available-income-per-household -in-china-by-region/.

Forsal 2018. Rosna nierówności w Chinach. Zagraża to konsumpcji i wzrostowi gospodarczemu. Pobrane z: https://forsal.pl/artykuly/1104349,rosna-nierownosci-w-chinach-zagraza-to-konsumpcji-i-wzrostowi-gospodarczemu.html. 